\title{
eHealth osaamisvaateet terveysalan ammattikorkeakoulukoulutuksessa
}

Pirkko Kouri, Jukka Seppänen

Savonia-ammattikorkeakoulu, Kuopio

Pirkko Kouri, terveydenhuollon teknologian yliopettaja, Savonia-ammattikorkeakoulu, Kuopio, FINLAND. Sähköposti: pirkko.kouri@savonia.fi.

\section{Tiivistelmä}

Teknologia mahdollistaa kansalaisten hoidon koordinoinnin eri palveluntuottajien välillä kansallisesti yli hallintorajojen. Myös rajat ylittävää hoitoa voidaan toteuttaa. Sähköinen arkistopalvelu parantaa asiakkaan hoitoa koskevan tiedon saantia sekä mahdollistaa kansalaisen osallisuuden itseään koskevaan päätöksentekoon. Ammattiin valmistuva sairaanhoitaja saa koulutuksensa aikana eHealth perustiedot ja -taidot. Tämän lisäksi sairaanhoitajat tarvitsevat monimuotoista koulutusta koko työuransa ajan. Teknologian kehittymisen myötä sairaanhoitajan työssä korostuu tieto- ja viestintätekniset taidot sekä interaktiivisen online viestintä- sekä vuorovaikutustaidot. Sairaanhoitajan työ muuttuu kohti potilaan omahoidon tukemista. Uusina rooleina ovat mentorointi, valmentaminen ja potilaan kumppanina oleminen. Sairaanhoitajien työolobarometrin (2016) mukaan suositus kuuden päivän vuotuisesta täydennyskoulutuksesta toteutui vain osin, sillä vain 30 prosenttia vastaajista ilmoitti käyneensä täydennyskoulutuksessa vähintään viisi päivää. Artikkeli kuvaa sairaanhoitajan eHealth -koulutusta ja haasteita, joihin koulutuksen on vastattava.

\section{Abstract}

The health care service chain of the citizen can be coordinated with the help of technology. Furthermore, the technology enables the cross-border care. The Finnish national archiving system supports citizen's own initiative and decision-making. Nurse learns basic eHealth skills and knowledges during her/his studies. However, the while working the nurse needs to update technology- know-how continuously. New technology bring new demands for nurse competences like information technology skills, diversified interpersonal skills, online-based communication and interaction skills. Today the nurse expertise is challenges more towards self-care of smart patients. The new roles of the nurse are mentoring, coaching and companionship with the patient. According to the recent Nurse barometer related to working conditions, only 30 percent of the nurses use their justified benefit, five-day's continuing training. The article describes nurse education and training from novice to expert, and the challenges nurses face.

\section{Johdanto}

Sosiaali- ja terveyspalvelut uudistuvat, sähköistyvät ja hakevat uusia uria kansallisen SOTE-reformin alla. Vaik- ka käynnissä oleva uudistus koskee koko sosiaali- ja terveysalan kenttää, tässä artikkelissa keskitytään terveysalaan. Digitalisaatio ei synny itsestään. Terveyspalvelujen digitalisoituminen, potilaiden itse toteuttamien 
terveysmittausten sekä teknologian tuomien mahdollisuuksien myötä terveydenhuollon koulutusta joudutaan kehittämään työelämän vaatimusten suuntaan. Digitalisaatio ja teknologian kehittyminen nähdäänkin yhtenä merkittävimpänä sosiaali- ja terveysalan toimintaympäristön muutoksen megatrendinä lähitulevaisuudessa. Terveydenhuollon koulutuksessa teknologiaosaamista tulee tarkastella kahdesta näkökulmasta. Toisaalta työelämän teknologisoitumisen näkökulmasta, jossa huomioidaan uusien teknologisten laitteiden, järjestelmien, ohjelmien sekä palveluiden kehittyminen sekä niiden tuomat uudet osaamisvaateet ja toisaalta pedagogisten ratkaisuiden teknologisoitumisen näkökulmasta. Suomi on linjannut hallitusohjelmansa yhdeksi strategiseksi tavoitteeksi olla koulutuksen, osaamisen ja modernin oppimisen kärkimaa vuonna 2025. Tämä edellyttää oppimisympäristöjen ajantasaistamista ja uusien pedagogisten mahdollisuuksien hyödyntämistä opetuksessa. Globaalit haasteet ja valtakunnalliset linjaukset haastavat meitä pohtimaan terveydenhuollon ammattilaisen työelämän osaamisvaateita. Kuinka hyvin ammattikorkeakoulujen opetussuunnitelmat vastaavat tämän päivän sekä lähitulevaisuuden asettamiin teknologian haasteisiin? Huomioidaanko korkeakoulujen opetussuunnitelmissa riittävästi opiskelijoiden työssä tarvitsema teknologiaosaaminen? Tulevaisuuden haasteet tulee huomioida terveydenhuollon valmistavassaja täydennyskoulutuksessa. Artikkelin esimerkkitapauksissa käytetään Savonia-ammattikorkeakoulua (Savonia) ja siellä käytössä olevia sähköisiä menetelmiä ja välineitä..

\section{Terveydenhuollon sähköisten leviäminen - haaste koulutukselle}

Digitaalisilla eli sähköisillä terveydenhuoltopalveluilla (eHealth) tarkoitetaan laajasti terveydenhuoltoalan välineitä ja palveluja, joissa käytetään tieto- ja viestintätekniikkaa. Ne käsittävät paitsi tietojen vaihdon potilaiden sekä terveydenhuollon palvelujen tarjoajien, sairaaloiden, terveysalan ammattilaisten ja terveysalan tietoverkkojen välillä myös monia muita sovelluksia, kuten sähköiset potilastietojärjestelmät, etäterveyspalvelut, kannettavat potilaiden seurantalaitteet, robotii- kan, terveyspelit ja ihmisen fysiologian virtuaalimallintamisen tutkimukset. Sähköisten palveluiden tavoitteena on ennalta ehkäistä sairauksia ja parantaa diagnosointia, hoitoa, seurantaa ja terveydenhuollon hallintoa. Tietosuoja- ja tietoturva-asiat läpäisevät terveysalan kaikkia toimintoja ja prosesseja ja siihen tarvitaan jatkuvaa koulutusta.

Tuoreen selvityksen mukaan terveydenhuollon teknologian haasteita ovat terveysalan ammattilaisten työkalujen muokkaaminen käytettävimmäksi ja kansalaisten sähköisten palvelujen kehittäminen. Työelämässä teknologian kehittämisen painopistealueet tulisikin olla asiakaslähtöinen toiminta, palvelurakenteen keventäminen, digitalisoidun työnsisältöjen kehittäminen ja palveluiden kohdentaminen eniten palveluja ja resursseja käyttäviin asiakasryhmiin. Selvityksen mukaan tiedolla johtamisen tuki terveydenhuollon tietojärjestelmissä on vielä kehittymätöntä. Tietoa joudutaan koostamaan useasta eri lähteestä ja seurantaan käytetään paljon erikseen tilattavia raportteja, vaikka monet terveydenhuollon työntekijät käyttävät jotain seurantajärjestelmää päivittäin. Myös tiedonhallinnan järjestelmissä koettiin puutteita sekä käytettävyydessä, että tiedon luotettavuudessa. Internetiin kerääntyy tietoa, big dataa, jatkuvasti valtavia määriä, useista eri lähteistä. Tietomassaan kohdistuvaa tutkimus- ja menetelmätietoutta kehitetään kaikkialla, sillä tietoaineistojen vapaalla saatavuudella tavoitellaan uusien palvelujen lisäksi palveluiden suunnitelmallisempaa käyttöä, yhteiskunnallista tehokkuutta ja läpinäkyvyyttä.

\section{Koulutus valmentaa sähköisten palveluiden hyödyntämiseen}

Terveysalan koulutuksessa on useamman vuoden ajan käytetty sulautuvaa opetusta tai oppimista riippuen tarkastellaanko asiaa opettajan tai opiskelijan näkökulmasta. Sulautuva opetus/oppiminen on yhdistelmä verkko-opetusta ja lähiopetusta opetus- tai oppimistavoitteiden kannalta mielekkäällä tavalla. Kansainvälisille opiskelijoille usein tulee yllätyksenä oppimismenetelmien kirjo. (Kuvio 1). 


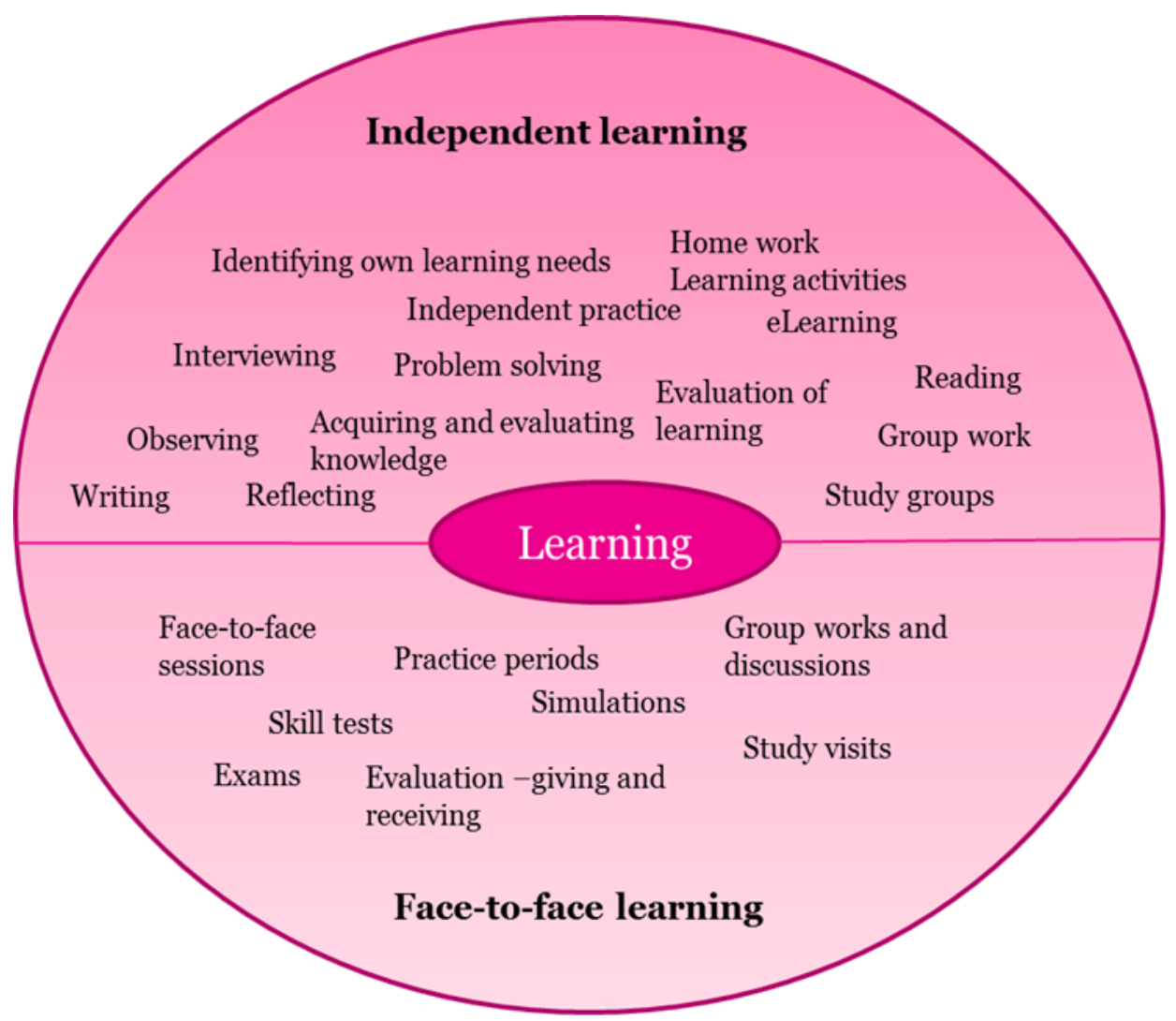

Kuvio 1. Oppimismenetelmät.

Teknologian ja internetin kehittymisen myötä ammattikorkeakoulutuksen (amk) pedagoginen ajattelu ja oppimisen filosofia muuttuu. Amk-koulutukseen on vahvasti tulossa käänteinen opetus, jossa on kyse yhteisöllisestä oppimisesta. Oppilas hyödyntää yhteisöä ja opettajaa väylänä omaan motivoitumiseensa. Myös sosiaalisen median rooli on kasvanut osana opetusta ja oppimista. Sosiaalinen media on teknologiaa käyttävä, rakenteinen, reaaliaikainen kanssakäyminen ja vuorovaikutteinen prosessi, jossa verkottuneet yksilöt ja ryhmät luovat vapaaehtoisesti yhteisiä merkityksiä sisältöjen, yhteisöjen ja verkkoteknologioiden avulla vertaistuotannon kautta.

Savonialla on käytössä Wilma-kouluhallintojärjestelmä, jota opiskelijat ja opettajat käyttävät oppimisen, ope- tuksen ja arvioinnin välineenä. Intranetissä löytyy opiskelijoille suunnattu Reppu-ympäristö, joka monipuolinen sähköinen ympäristö opiskelijoiden opiskelun tukemiseksi. Reppu sisältää opiskelutaitoihin liittyvää informointia sekä yleistä tiedotusta kampuksella tapahtuvasta toiminnasta. Repussa on käytössä myös erilaisia oppimiseen ja opiskelijana olemiseen liittyviä blogeja.

Savoniassa eOpetuksen/oppimisen sekä lisääntyvässä määrin myös työelämäyhteistyön välineenä käytetään laajasti erilaisia langattomien sovellusten sekä sosiaalisen median tuomia mahdollisuuksia. (Kuvio 2) 


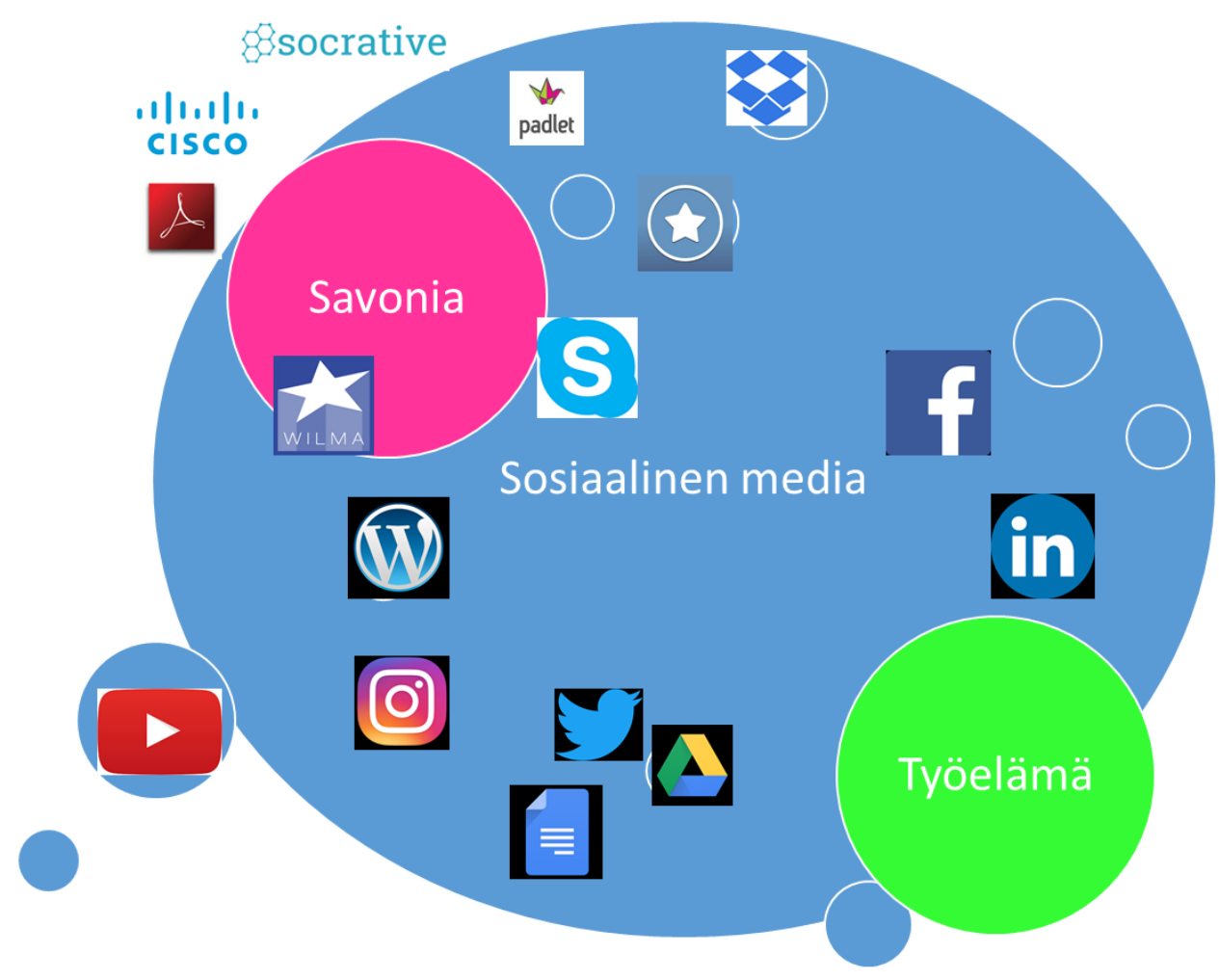

Kuvio 2. Sosiaalinen media moniammatillisen osaamisen kehittämisen tukena.

Videoneuvotteluohjelmia (AdobeConnect Pro, Cisco, Skype for Business, Lync) hyödynnetään opetus- ja verkkoseminaarien toteutuksissa. Lisäksi videoneuvottelua käytetään opiskelijoiden opinnäyte- ja ryhmätöiden sekä opintojen ohjauksen välineenä sekä henkilökunnan ja työelämän välisessä jatkuvassa yhteydenpidossa. Sähköisenä oppimisympäristönä Savoniassa käytetään Moodlea, joka toimii kiinteästi eri koulutusohjelmien opintojaksojen toteutuksessa. Moodle toimii oppimistehtävien palautus, reflektointi ja arviointialustana. Yhteydenpito opettajan kanssa voidaan toteuttaa Moodlen kautta, vaikka reaaliaikaisesti. Osaamisen arvioimisessa hyödynnetään myös Examtenttiympäristöä, jossa opiskelija voi suorittaa tentin hänelle sopivana ajankohtana.

Savoniassa käytetään PLE (Personal Learning Environment)-ajattelun mukaista oppimista, jolloin käyttäjä luo oman ympäristönsä johonkin sosiaalisen median palveluun. Opiskelijat käyttävät blogia muun muassa oman osaamisen kehittymisen päiväkirjana ja yhteistyön väline opettajien ja vertaisten kanssa. Savoniassa on ope- tushenkilöstön sekä opiskelijoiden käytössä myös lukuisia muita sosiaalisen median palvelut. (Kuvio 2)

\section{eHealth osaamisvaateet hoitotyössä}

Sairaanhoitajan toimintaa ohjaa lainsäädäntö ja terveyspoliittiset linjaukset. Sairaanhoitajan osaamisvaatimuksissa digitalisaatio ja teknologia sisältyvät ammatillisiin kompetensseihin. Tavoitteen mukaan amk:sta valmistuva hyödyntää tieto- ja viestintäteknologiaa, sähköisiä palveluja sekä sosiaalista mediaa asiakkaan kokonaishoidossa. Hän hallitsee kliinisessä hoitotyössä keskeisten hoito- ja valvontalaitteiden käytön ja käyttää tietoturvallisesti potilastietojärjestelmiä.

Uudet terveysteknologian järjestelmät ja laitteet asettavat suuret haasteet terveydenhuollon ammattilaisen asiantuntijuudelle ja osaamiselle ja täydennyskoulutuksen tarve onkin jatkuvaa. Terveysalan oleellisia osaamisvaateita ovat tieto- ja viestintätekniset taidot, interaktiiviset online viestintä ja vuorovaikutustaidot, oman 
itsensä johtamistaidot ja asiantuntijuus sekä kokonaisuuksien hahmotus, sillä sähköiset palvelut muodostavat laaja-alaisen, moniammatillisen kontekstin, jossa myös asiakkaat tarvitsevat tukea ja ohjausta palveluiden tehokkaaseen hyödyntämiseen.

\section{Pohdinta}

eHealth osaamista ei tulisi kehittää teknologia edellä. Käytettävän teknologian on oltava tarkoituksenmukais- ta, eettisesti kestävää ja lisäarvoa tuottavaa, oli kyseessä koulutus tai hoitotyö. Haasteena on, että suuri osa hoitotyön tekijöistä on käynyt peruskoulutuksen ennen hoitotyön digitalisoitumista. He tarvitsevat tukea, riittävästi resursseja ja koulutusta työstä selviytymiseen sekä oman työnsä kehittämiseen. Uusia sovelluksia ja välineitä tulee koko ajan ja on muistettava, ettei teknologian viihdekäyttö takaa asiantuntijuutta teknologian ammattikäyttöön. 